\title{
PEMBELAJARAN BERBASIS TRAINER PENGENDALI ELEKTROMAGNETIK UNTUK MENINGKATKAN HASIL BELAJAR SISWA
}

\author{
Fivia Eliza ${ }^{1}$, Radinal Fadli ${ }^{2}$, Angga Mardani $^{3}$ \\ 1,2,3 Teknik Elektro, Fakultas Teknik, Universitas Negeri Padang \\ E-mail: fivia_eliza@yahoo.com
}

\begin{abstract}
The problem in learning Electromagnetic Control System that implemented at SMKN 1 Padang is about media. This research is oriented because there are many students learning outcomes that still not reach the KKM at Electromagnetic Control System subject grade XI TITL in SMKN 1 Padang. There are many factor which influence the low of students learning outcomes such as learning process by using conventional method and media that used by teacher in learning are module and only use the whiteboard. Based on these factors, then conducted the research in experiment form to increase students learning outcomes by using learning media of electromagnetic control trainer. The method that use in this research is quasi experiment with Pretest-Posttest One Group Design. Subject of this research are students grade XI TITL A SMKN 1 Padang, which consist of 31 students. Data collecting in the research use objective test (Pretest-Posttest). The result of research indicated that there is an increasing of students learning at Electromagnetic Control System subject. Increasing occurs at high level $(0,71)$ where 18 students are on high level and 13 others are on middle level increasing.
\end{abstract}

Key words : Learning Media, Trainer, Electromagnetic Control System

\begin{abstract}
ABSTRAK
Penelitian ini dilatarbelakangi oleh proses pembelajaran yang berpusat pada guru (teacher centered) yang mengakibatkan banyaknya hasil belajar siswa yang belum mencapai KKM pada mata pelajaran Sistem Pengendali Elektromagnetik kelas XI TITL di SMKN 1 Padang. Banyak faktor yang mempengaruhi rendahnya hasil belajar siswa diantaranya adalah proses pembelajaran dengan metode yang bersifat kovensional dan media yang digunakan oleh guru dalam pembelajaran berupa modul dan menggunakan papan tulis saja. Berdasarkan faktor tersebut, maka dilakukan penelitian untuk meningkatkan hasil belajar siswa dengan menggunakan media trainer pengendali elektromagnetik. Metode yang digunakan pada penelitian ini adalah quasi eksperimen dengan Pretest-Posttest One Group Design. Subjek penelitian ini adalah siswa kelas XI TITL A SMKN 1 Padang, yang terdiri dari 31 orang siswa. Pengumpulan data dalam penelitian ini menggunakan tes (Pretest-Postest) berupa soal objektif. Soal tes yang digunakan terlebih dahulu dilakukan ujicoba untuk mengetahui validitas, reliabilitas, tingkat kesukaran, dan daya pembeda soal. Berdasarkan hasil ujicoba, diperoleh 25 item soal tes sebagai instrumen penelitian.Hasil penelitian dan analisis data menunjukkan bahwa terdapat peningkatan hasil belajar siswa kelas XI TITL di SMKN 1 Padang pada mata pelajaran Sistem Pengendali Elektromagnetik. Peningkatan yang terjadi berada pada taraf tinggi $(0,71), 18$ orang siswa mengalami peningkatan taraf tinggi dan 13 siswa lainnya mengalami peningkatan taraf sedang.
\end{abstract}

Kata kunci : media trainer, pengendali elektromagnetik, hasil belajar

\section{PENDAHULUAN}

Pada intinya pendidikan itu bertujuan untuk membentuk karakter seseorang yang beriman dan bertakwa kepada Tuhan Yang
Maha Esa. Akan tetapi, pendidikan hanya menekankan pada intelektual saja, dengan bukti bahwa adanya Ujian Nasional (UN) sebagai tolak ukur keberhasilan pendidikan tanpa melihat proses pembentukan karakter dan budi 
pekerti peserta didik. Undang-Undang Nomor 20 tahun 2003 tentang Sistem Pendidikan Nasional, Pasal 3, menyatakan bahwa "tujuan pendidikan nasional adalah mengembangkan potensi peserta didik agar menjadi manusia yang beriman dan bertakwa kepada Tuhan Yang Maha Esa, berakhlak mulia, sehat, berilmu, cakap, kreatif, mandiri, dan menjadi warga negara yang demokratis serta bertanggung jawab.

Pendidikan kejuruan merupakan pendidikan yang diharapkan agar lulusannya dapat langsung mendapatkan pekerjaan yang sesuai dengan pendidikan dan keahlian yang telah dipelajari selama menempuh jenjang pendidikan pada program pendidikan kejuruan. SMK bertujuan menyiapkan peserta didik agar dapat bekerja, baik secara mandiri atau mengisi lowongan pekerjaan yang ada di DU/DI sebagai tenaga kerja tingkat menengah, sesuai dengan bidang keahlian dan program keahlian yang diminatinya" (Kuswana, 2013). Sementara itu pendidikan kejuruan bertujuan untuk memberikan bekal keterampilan yang dapat digunakan di masyarakat, sehingga hal itu dapat menunjang kehidupan ekonominya, membantu peserta didik memperoleh dan mempertahankan pekerjaan yang diinginkannya, mendorong produktivitas ekonomi secara ekonomi secara regional maupun nasional, mendorong tumbuhnya tenaga terlatih untuk menopang pertumbuhan ekonomi dan industri, serta mendorong peningkatan kualitas masyarakat. Pendidikan kejuruan diadakan atas dasar untuk memenuhi kebutuhan masyarakat dan kebutuhan dunia usaha dan industri” (Wingkel, 1996).

Berdasarkan hasil observasi yang dilakukan di SMK Negeri 1 Padang terlihat bahwa guru mata pelajaran Sistem Pengendali Elektromagnetik menguasai materi yang diajarkan dan telah memiliki kesiapan untuk melakukan proses pembelajaran. Namun masih banyak siswa yang kurang aktif (kurangnya minat siswa dalam belajar) saat proses pembelajaran Pengendali Elektro-magnetik. Selain itu, belum tercapainya ketuntasan belajar yang telah ditetapkan kepada siswa khususnya pada mata pelajaran Sistem Pengendali Elektromagnetik, yang semuanya itu berdampak negatif terhadap pemahaman materi yang diberikan guru selanjutnya. Kemudian, belum tersedianya media pembelajaran yang dapat mensimulasikan atau mendemonstrasikan sebuah rangkaian pengontrolan sebagai bagian terpenting dalam mata pelajaran Sistem Pengendali Elektromagnetik.

Ketika proses pembelajaran dimulai, seorang guru akan mencatat materi yang akan dibahas di papan tulis, kemudian guru menjelaskannya, siswa mencatat dan mendengarkan materi yang telah ditulis dan dijelaskan oleh guru. Pada saat proses pembelajaran guru cenderung hanya memilih media papan tulis dalam penyampaian materi kepada siswa di kelas. Pada akhir pertemuan siswa akan diberi tugas berupa pertanyaaanpertanyaan menyangkut materi yang telah dibahas. Pembelajaran seperti ini menimbulkan beberapa permasalahan, antara lain: banyak siswa yang tidak fokus dalam mengikuti proses pembelajaran selama proses pembelajaran berlangsung, tidak terjalin komunikasi dua arah antara guru dan siswa, banyak siswa yang tidak berpartisifasi aktif selama proses pembelajaran berlangsung. Selain itu dapat mengakibatkan hasil belajar akhir siswa tidak mencapai nilai Kriteria Ketuntasan Minimal (KKM) yang telah ditetapkan oleh sekolah. Hal tersebut dibuktikan dengan masih banyaknya hasil belajar akhir siswa dibawah nilai KKM.

Mata pelajaran Sistem Pengendali Elektromagnetik di SMKN 1 Padang, standar ketuntasan minimal yang ditetapkan adalah 70 . Berdasarkan hasil belajar siswa kelas XI SMKN 1 Padang tahun 2017/2018 yang didapatkan dari guru mata pelajaran tersebut, maka dapat diketahui bahwa masih banyak hasil belajar siswa yang belum mencapai KKM, kelas XI TITL A 66,67\% hasil belajar siswa di bawah KKM, kelas XI TITL B 70\% hasil belajar siswa dibawah KKM. Hal ini membuktikan bahwa masih banyak siswa yang 
belum tuntas dalam mata pelajaran sistem pengendali elektromagnetik tersebut.

Berdasarkan hasil diatas, maka perlu dicari alternatif lain dengan melakukan inovasi dan pendekatan untuk penyampaian materi kepada siswa pada saat berlangsungnya proses pembelajaran di kelas, sehingga proses pembelajaran dapat berlangsung aktif, inovatif, kreatif, efektif, dan menyenangkan serta hasil belajar siswa yang baik. Salah satu pendekatan yang diduga mampu mewujudkan situasi pembelajaran tersebut adalah dengan pembelajaran menggunakan media trainer pengendali elektromagnetik.

Proses pembelajaran adalah suatu proses atau kegiatan antara peserta didik dengan guru, dan antara peserta didik dengan sesamanya, dimana proses belajar ini dilaksanakan di lingkungan tertentu. Untuk mendapatkan hasil yang optimal maka interaksi antar peserta didik dengan guru, guru dengan peserta didik dirancang sedemikian rupa. Belajar dan mengajar merupakan suatu kegiatan yang berbeda tetapi di antara keduanya tidak dapat dipisahkan satu sama lainnya. Dalam proses belajar mengajar tersebut timbul perubahan tingkah laku pada diri siswa. Belajar merupakan suatu proses yang kompleks yang terjadi pada semua orang dan berlangsung seumur hidup. Belajar bukan hanya karena keberadaan pengajar, tetapi belajar merupakan suatu proses yang terjadi di dalam diri akibat interaksi dengan lingkungan yang dapat dilakukan kapan saja, dimana saja, sehingga diperoleh suatu pengalaman (Kuswana, 2013).

Proses belajar terjadi pada diri setiap orang sepanjang hidupnya. Belajar merupakan suatu proses yang ditandai oleh adanya perubahan pada diri seseorang, misalnya dari tidak tahu menjadi tahu, dari tidak mengerti menjadi mengerti. Indikator lain yang menyatakan bahwa seseorang itu telah mengalami proses belajar adalah adanya perubahan tingkah laku pada diri seseorang yang disebabkan oleh terjadinya perubahan pada tingkat pengetahuan, keterampilan atau sikapnya. Belajar adalah suatu aktivitas mental atau psikis, yang berlangsung dalam interaksi aktif dengan lingkungannya, yang menghasilkan perubahan-perubahan dalam pengetahuan pemahaman, keterampilan dan nilai sikap. Perubahan-perubahan tersebut berlangsung relatif konstan dan berbekas (Wingkel, 1996).

Proses pembelajaran merupakan interaksi antara siswa dengan guru dimana setiap unsur memiliki perannya masing-masing. Peranan guru adalah membelajarkan siswa agar tujuan pendidikan tercapai yaitu membentuk manusia yang cerdas, terampil dan berbudi pekerti luhur sedangkan peranan siswa adalah mengikuti secara aktif dalam kegiatan pembelajaran sehingga materi pembelajaran dapat dipahami dengan baik. Pengajaran akan bersifat efektif jika a) berpusat kepada siswa yang aktif, bukan hanya guru; b) terjadi interaksi edukatif diantara guru dengan siswa; c) berkembang suasana demokratis; d) metode mengajar bervariasi; e) gurunya profesional; f) apa yang dipelajari bermakna bagi siswa; g) lingkungan belajar kondusif; serta h) sarana dan prasarana belajar sangat menunjang. Saat ini proses pembelajaran diarahkan untuk mengaktifkan siswa agar dapat mengembangkan kemampuan yang dimilikinya (Triatna, 2009).

Oleh karena itu, diperlukan berbagai usaha, diantaranya guru harus mampu menggunakan media dan metode yang dapat meningkatkan aktivitas siswa dalam belajar. Pada suatu kondisi tertentu peserta didik merasa bosan dengan metode atau media yang tidak bervariasi, misalnya guru hanya menggunakan metode ceramah maka, mereka di tuntut untuk setia dan tenang mendengarkan penjelasan guru. Pembelajaran seperti ini harus dialihkan agar hasil belajar yang diinginkan bisa tercapai.

Media berasal dari bahasa Latin medius yang secara harfiah berarti "tengah, perantara, atau pengantar". Gagne menyatakan bahwa "media adalah berbagai jenis komponen dalam lingkungan siswa yang dapat merangsangnya untuk belajar" (Triatna, 2009).

Media memiliki peranan penting yaitu piranti (wahana) penyalur pesan atau informasi. 
Media yang digunakan dalam dunia pendidikan disebut media pembelajaran. Gagne dan Briggs menyatakan bahwa media pembelajaran meliputi alat yang secara fisik digunakan untuk menyampaikan isi materi pengajaran yang terdiri dari buku, tape recorder, kaset, video camera, video recorder, film, slide (gambar bingkai), foto, gambar, grafik, televisi, dan komputer. Berdasarkan uraian diatas, penggunaan media pembelajaran harus didasarkan pada pemilihan yang tepat, sehingga dapat memperbesar arti dan fungsi dalam menunjang efektivitas dan efisiensi proses pembelajaran (Ganefri, 2013).

Dengan memperhatikan kompleks dan uniknya proses belajar, maka ketepatan pemilihan media dan metode pembelajaran akan sangat berpengaruh terhadap hasil belajar siswa. J Bruner mengemukakan bahwa dalam proses pembalajaran hendaknya menggunakan urutan dari belajar dengan gambaran atau film (iconic representation of experiment) kemudian ke belajar dengan simbol, yaitu mengunakan kata-kata (symbolic representation) (Prayoga Iqbal Nuryasied, 2013). Edgar Dale mengelompokkan media pembelajaran berdasarkan jenjang pengalaman yang diperoleh pembelajar (Ganefri, 2013).

Trainer merupakan suatu set peralatan di laboratorium yang digunakan sebagai media pendidikan yang merupakan gabungan antara model kerja dan mock-up. Trainer ditujukan untuk menunjang pembelajaran peserta didik dalam menerapkan pengetahuan/konsep yang diperolehnya pada benda nyata. Model mock-up adalah suatu penyederhanaan susunan bagian pokok dari suatu proses atau sistem yang lebih ruwet" (Ganefri, 2013).

$\begin{array}{ccr}\text { Media } & \text { trainer } & \text { pengendali } \\ \text { elektromagnetik } & \text { merupakan } & \text { media }\end{array}$
pembelajaran yang digunakan untuk membantu guru dalam menjelaskan beberapa teori yang membutuhkan contoh langsung agar dapat mempermudah pemahaman siswa terhadap materi pelajaran yang dijelaskan oleh guru. Media trainer ini digunakan terutama untuk membantu penjelasan materi dalam proses pembelajaran teori. Dengan menerapkan media trainer pengendali elektromagnetik ini dapat mempermudah siswa memahami beberapa materi yang disampaikan oleh guru terkait dengan materi-materi pembelajaran yang membutuhkan contoh fisik sebelum melaksanakan praktikum di dalam laboratorium atau workshop. Siswa dalam pelaksanaan pembelajaran teori dapat memahami penerapan dari teori-teori yang diajarkan. Media trainer pengendali elektromagnetik dalam penerapannya digunakan oleh guru didepan kelas sebagai media demonstrasi, simulasi, serta media nyata. Media trainer pengendali elektromagnetik dapat membantu guru dalam menjelaskan materi dan membantu siswa untuk memahaminya. Materi pembelajaran pada mata pelajaran sistem pengendali elektromagnetik terdiri dari materi yang membahas tentang peralatan dan bahan yang dibutuhkan dalam membuat sistem pengendali elektromagnetik serta bentuk rangkaian-rangkaian yang digunakan untuk membuat sistem pengendali elektromagnetik dalam beberapa penerapan dan aplikasinya. Dengan sifat materi yang demikian dibutuhkan media pembelajaran yang dapat memenuhi penyampaian materi tersebut, maka dengan menggunakan media trainer pengendali elektromagnetik inilah siswa dapat memahami dengan mudah materi-materi pelajaran yang ada pada mata pelajaran sistem pengendali elektromagnetik.

Belajar merupakan proses perubahan diri seorang individu menjadi lebih baik dari sebelumnya. Hasil dari proses belajar antara lain berupa peningkatan pengetahuan seseorang, bertambahnya keterampilan dan kemampuan serta perubahan sikap seseorang menjadi lebih baik dari sebelumnya. Keterkaitan antara guru dan siswa dalam proses pembelajaran akan mempengaruhi tercapainya tujuan pembelajaran yang lebih baik. Siswa perlu mengadakan interaksi sosial tidak hanya dengan guru tapi juga interaksi dengan siswa lain dan bukan menerima pengetahuan dari guru secara pasif. Untuk mencapai keberhasilan dalam kegiatan pembelajaran diperlukan 
beberapa komponen penunjang diantaranya yaitu komponen tujuan, komponen materi, komponen strategi pembelajaran, dan komponen evaluasi. Masing-masing komponen tersebut saling terkait dan saling mempengaruhi satu sama lain.

Secara harfiah, media berasal dari bahasa latin 'medius' yang berarti tengah, perantara dan pengantar. Sedangkan menurut bahasa arab media berarti perantara atau pengantar pesan dari pengirim kepada penerima pesan. Pada prinsipnya, penggunaan media dalam pembelajaran adalah untuk membantu mempermudah tercapainya tujuan pembelajaran.

Ditinjau dari kesiapan pengadanya, media dikelompokkan dalam dua jenis, yaitu media jadi karena sudah menjadi komoditi perdagangan dan terdapat dipasaran luas dalam keadaan siap pakai (media by utilization), dan media rancangan karena perlu dirancang dan perlu dipersiapkan secara khusus untuk maksud dan tujuan pembelajaran tertentu (media by design) (Mukhtar dan Iskandar, 2010).

$\begin{array}{ccr}\text { Media } & \text { trainer } & \text { pengendali } \\ \text { elektromagnetik } & \text { merupakan } & \text { media }\end{array}$
pembelajaran yang digunakan untuk membantu guru dalam menjelaskan beberapa teori yang membutuhkan contoh langsung agar dapat mempermudah pemahaman siswa terhadap materi pelajaran yang dijelaskan oleh guru. Media trainer ini digunakan terutama untuk membantu penjelasan materi dalam proses pembelajaran teori. Dengan menerapkan media trainer pengendali elektromagnetik, dapat mempermudah siswa memahami beberapa materi yang disampaikan oleh guru terkait dengan materi-materi pembelajaran yang membutuhkan contoh fisik sebelum melaksanakan praktikum di dalam laboratorium atau workshop. Siswa dalam pelaksanaan pembelajaran teori dapat memahami penerapan dari teori-teori yang diajarkan.

Kompetensi dasar yang akan digunakan pada penelitian ini adalah mengoperasikan peralatan dengan sistem pengendali mekanik menggunakan relay, kontaktor, pembatas arus dan saklar batas dengan materi ajar pengendalian motor 1 fasa menggunakan saklar magnet, pengendalian motor 1 fasa menggunakan saklar magnet dengan tombol on dan off dikendalikan dari banyak tempat, pengendalian motor 3 fasa menggunakan saklar magnet dengan merubah arah putaran, pengendalian motor 3 fasa bintang-segitiga dengan menggunakan saklar magnet.

\section{METODE}

Metode yang digunakan dalam penelitian ini adalah quasi ekperiment (eksperimen semu). Pretest dilakukan sebelum melaksanakan pembelajaran, untuk mengetahui pengetahuan awal siswa. Sementara posttest dilaksanakan setelah proses pembelajaran dengan menerapkan penggunaan media trainer pengendali elektromagnetik sebagai media pembelajaran. Hasil posttest dibandingkan dengan hasil pretest untuk mengetahui peningkatan hasil belajar siswa setelah pembelajaran dengan menggunakan media trainer pengendali elektromagnetik.

Penelitian ini menggunakan desain One Group Pretest - Posttest. Sekelompok subjek diberi perlakuan untuk jangka waktu tertentu berupa pembelajaran dengan menggunakan media trainer pengendali elektromagnetik. Dalam desain ini, pengukuran dilakukan dua kali. Pengukuran pertama dilakukan sebelum perlakuan. Pengukuran kedua dilakukan setelah perlakuan diberikan.

Subjek dalam penelitian ini adalah kelas XI TITL A SMK Negeri 1 Padang pada semester ganjil Juli-Desember 2017. Jumlah subjek penelitian adalah sebanyak 31 siswa. Subjek penelitian ditentukan secara random dari dua kelas jurusan teknik instalasi tenaga listrik di SMKN 1 Padang yang memiliki kemampuan rata-rata yang sama, hal ini dapat dilihat dari nilai rata-rata kelas dari ujian KD 1 Sistem Pengendali Elektromagnetik yang homogen dimana rata-rata kelas XI TITL A adalah 70,16, kelas XI TITL B adalah 71,70. 
Instrumen yang digunakan dalam penelitian ini adalah berupa soal-soal test berbentuk objektif. Soal tes dibuat berdasarkan kisi-kisi soal yang mengacu pada silabus dan rencana pelaksanaan pembelajaran mata pelajaran Sistem Pengendali Elektromagnetik SMKN 1 Padang. Sebelum soal tes digunakan maka dilakukan uji coba soal untuk mengetahui validitas, reliabilitas, tingkat kesukaran dan daya beda soal tersebut. Uji coba soal dilakukan di kelas XI TITL B SMK N 1 Padang.

Penafsiran harga validitas dianalisis menggunakan teknik korelasi point biserial. berdasarkan analisis data uji coba terhadap 30 soal Uji coba, terdapat 25 soal valid dan 5 soal yang tidak valid. Penafsiran harga reliabilitas tes berdasarkan perhitungan rumus Kuder Richardson (KR-20) dengan memperlihatkan kriteria reabilitas, maka keseluruhan soal tes dinyatakan reliabel dengan kriteria sangat tinggi. Hasil perhitungan tingkat kesukaran dianalisis menggunakan teori yang dikemukakan Arikunto. Berdasarkan hasil analisis dari soal uji coba sebanyak 30 soal, terdapat 21 soal dengan kriteria sedang, 8 soal dengan kriteria mudah, 1 soal dengan kriteria sukar. Perhitungan daya beda dianalisis menggunakan rumus yang dikemukakan oleh Arikunto, berdasarkan hasil analisis dari soal uji coba sebanyak 30 soal, didapat 13 soal kategori baik, 13 soal kategori cukup, dan 4 kategori jelek.

Data hasil belajar siswa dianalisis dengan menggunakan statistik deskriptif yaitu menghitung rata-rata skor (mean) dan simpangan baku standar deviasi. Peningkatan hasil belajar siswa dapat diukur dengan memberikan pretest dan posttest. Peningkatan hasil belajar dianalisis menggunakan Gain Score untuk melihat tingkat perolehan skor dari penerapan media trainer pengendali elektromagnetik pada mata pelajaran Sistem Pengendali Elektromagnetik.

\section{HASIL DAN PEMBAHASAN}

Data penelitian ini adalah data hasil belajar SPE. Kelas XI TITL A sebagai subjek penelitian yang diajar dengan menggunakan media trainer pengendali elektromagnetik, hasil pretest yang diadakan sebelum pembelajaran diperoleh skor tertinggi $=76$ dan skor terendah = 24 dengan jumlah siswa 31 orang. Dengan perhitungan statistik diperoleh hasil rata-rata skor $\mathrm{X}$ (pretest) adalah $=50,6$, simpangan baku $(s)=14,11$. Sebaran data frekuensi dapat dilihat pada tabel 1 dan gambar 1 .

Tabel 1. distribusi frekuensi pretest

\begin{tabular}{cll}
\hline No & Nilai & Frekuensi \\
\hline $\mathbf{1}$ & $23-31$ & 3 \\
$\mathbf{2}$ & $32-40$ & 6 \\
$\mathbf{3}$ & $41-49$ & 4 \\
$\mathbf{4}$ & $50-58$ & 7 \\
$\mathbf{5}$ & $59-67$ & 7 \\
$\mathbf{6}$ & $68-76$ & 4 \\
\hline
\end{tabular}

Untuk lebih jelas berikut adalah histogram data hasil pretest.

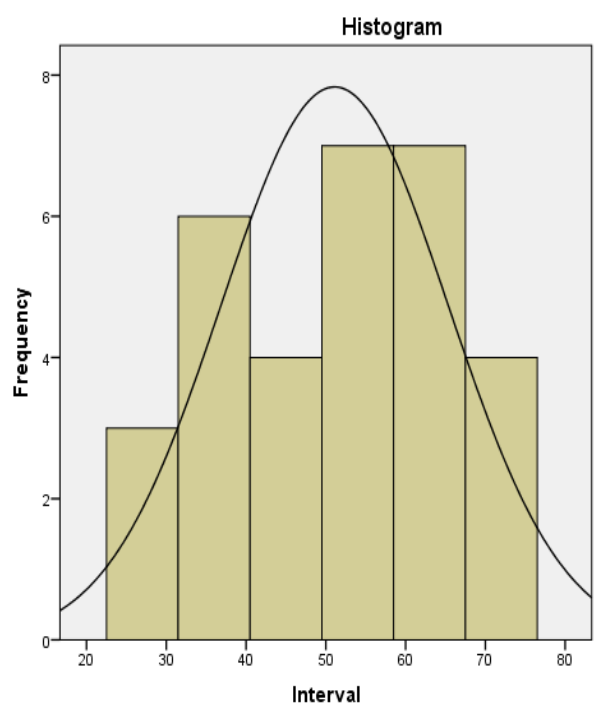

Gambar 1. Histogram data hasil pretest

Adapun hasil post-test yang diadakan setelah pembelajaran, skor tertinggi $=96$ dan yang terendah 68 . Untuk rata rata skor adalah $=$ 82,42 . Simpangan baku 6,81. Sebaran data frekuensi dapat dilihat pada Tabel 2.

Tabel 2. Distribusi frekuensi posttest

\begin{tabular}{l|l|l} 
No & Nilai & Frekuensi \\
\hline
\end{tabular}




\begin{tabular}{|c|c|c|}
\hline 1 & $67-71$ & 1 \\
\hline 2 & $72-76$ & 5 \\
\hline 3 & $77-81$ & 2 \\
\hline 4 & $82-86$ & 6 \\
\hline 5 & $87-91$ & 10 \\
\hline 6 & $92-96$ & 7 \\
\hline
\end{tabular}

Untuk lebih jelas berikut adalah histogram data hasil posttest.

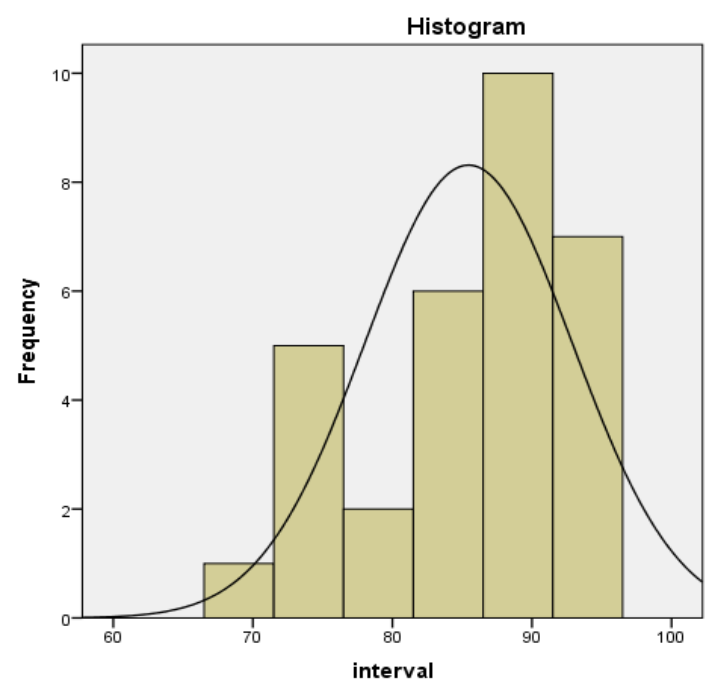

Gambar 2. Histogram data hasil posttest

\section{Analisis Peningkatan Hasil Belajar}

Peningkatan hasil belajar siswa dalam suatu proses pembelajaran dapat diukur dengan memberikan pretest dan posttest. Peningkatan hasil belajar dapat dianalisis menggunakan gainscore (Hake, 1999) dengan rumus sebagai berikut:

$$
<g>=\frac{\left(<S_{f}>-<S_{i}>\right)}{\left(100-<S_{i}>\right)}
$$

Dari perhitungan Gain score didapatkan bahwa semua hasil belajar siswa mengalami peningkatan. Rata-rata kenaikan hasil belajar di tentukan menggunakan rumus Gain Score = 0,71 dengan kriteria perolehan Gain Score pada rentang $\mathrm{NG} \geqq 0,7$ yaitu kategori tinggi. Ini berarti peningkatan hasil belajar siswa termasuk dalam kategori tinggi. Dengan demikian dapat dijelaskan bahwa hasil belajar siswa setelah pembelajaran dengan menggunakan Media trainer pengendali elektromagnetik mengalami peningkatan.

\section{Pembahasan}

Berdasarkan hasil penelitian, penerapan Media trainer pengendali elektromagnetik dapat membuat siswa lebih aktif dan lebih berpartisipasi dalam dalam proses pembelajaran. Penerapan media trainer pengendali elektromagnetik mempunyai manfaat positif apabila diterapkan di ruang kelas. Pada penelitian ini menggunakan uji Gain Score. Pertama dilakukan pre-test untuk melihat kemampuan awal siswa sebelum menerapkan media trainer pengendali elektromagnetik. Dari hasil pretest diperoleh rata-rata hasil belajar siswa sebesar $=50,6$. Kemudian dilakukan uji normalitas dan didapat bahwa data terdistribusi normal. Setelah melihat kemampuan awal maka diberi perlakuan dengan menggunakan media trainer pengendali eletromagnetik selama empat minggu sebanyak empat kali pertemuan kemudian diberi posttest. Dari hasil perhitungan data setelah diberi perlakuan didapatkan ratarata hasil belajar siswa sebesar 85,42. Kemudian dilakukan uji normalitas dan didapat bahwa data terdistribusi normal. Langkah berikutnya adalah melihat peningkatan hasil belajar siswa dengan menggunakan Gain Score dan didapat bahwa hasil belajar siswa mengalami peningkatan dengan kategori tinggi.

Dari penjelasan di atas, Penerapan media trainer pengendali elektromagnetik dapat meningkatkan hasil belajar siswa, karena adanya peningkatan hasil belajar yang signifikan antara pretest dan posttest. Kemudian dianalisis menggunakan rumus Gainscore didapatkan peningkatan hasil belajar siswa setelah pembelajaran menggunakan media trainer, berada pada taraf sedang $(\langle g\rangle$ $=0,64$ ).

Berdasarkan penelitian yang dilakukan terdapat beberapa kendala dalam menerapkan media trainer pengendali elektromagnetik ini, salah satunya adalah ada beberapa siswa yang tidak hadir. 


\section{SIMPULAN}

Berdasarkan hasil analisis data dapat disimpulkan bahwa terdapat peningkatan hasil belajar siswa dengan mengadakan pembelajaran berbasis trainer. Hal ini dapat dilihat dari :

a. Hasil belajar siswa dalam mata pelajaran Sistem Pengendali Elektromagnetik kelas XI dengan menggunakan media trainer pengendali elektromagnetik sebagai media pembelajaran dalam proses pembelajaran di kelas didapatkan nilai rata-rata dari 31 orang siswa yaitu 85,42 .

b. Hasil belajar siswa setelah dilaksanakan proses pembelajaran dengan menggunakan media trainer pengendali elektromagnetik sebagai media pembelajaran (nilai posttest) lebih baik jika dibandingkan dengan nilai sebelumnya (nilai pretest).

c. Peningkatan hasil belajar siswa yang terjadi termasuk pada kategori tinggi yaitu 0,71 , dengan demikian dapat dijelaskan bahwa hasil belajar siswa pada mata diklat Sistem Pengendali Elektromagnetik setelah proses pembelajaran dilakukan dengan menggunakan media trainer pengendali elektromagnetik sebagai media pembelajaran mengalami peningkatan.

\section{DAFTAR RUJUKAN}

Asyhar Rayandra. 2012. Kreatif Mengembangkan Media Pembelajaran. Jakarta: Refrensi Jakarta.

Azhar Arsyad. 2013. Media Pembelajaran. Jakarta: Rajawali Pers.
Ganefri. 2013. Tujuan Pendidikan Menurut Thorogood. Padang: UNP Press

Hake, R. R. 1999. Analizing Change/Gain Scores. [Online]. Tersedia: http://www.physics.indiana.edu/ sdi/Ana lyzingChange-Gain.pdf. [18. November 2016].

Kuswana, 2013. Sebab didirikan SMK. Jakarta: Gaung Persada Press Jakarta.

Mukhtar dan Iskandar. 2010. Desain Pembelajaran Berbasis Teknologi Informasi dan Komunikasi. Jakarta: Gaung persada press.

Nana Sudjana. 2010. Strategi Pembelajaran. Bandung: Falah Production.

Prayoga Iqbal Nuryasied. 2013. Penerapan Media Belajar Trainer PLC Omron Portable Untuk Meningkatkan Hasil Belajar Siswa Tentang Pemograman PLC. Skripsi. Universitas Pendidikan Indonesia: tidak diterbitkan

Sugyono. 2015. Metode Penelitian \& Pengembangan Research and Development. Bandung: Alfabeta.

Suharsimi Arikunto. 2013. Dasar-dasar Evaluasi Pendidikan. Jakarta: Bumi Aksara.

Triatna. 2009. Model Pembelajaran InovatifProgresif. Jakarta : Kencana.

Wingkel. 1996. Psikologi Pengajaran. Jakarta : Grasindo. 